\title{
Microstructure of New Cobalt Alloy for Medical Use
}

Kateřina Nová1, Pavel Novák ${ }^{1}$, Anna Knaislová1, Drahomír Dvorský1 ${ }^{1}$, Jiří Zýka ${ }^{2}$

${ }^{1}$ University of Chemistry and Technology, Prague, Department of Metals and Corrosion Engineering, Technická 5, 166

28 Prague 6, Czech Republic, E-mail: kety.n@seznam.cz

${ }^{2}$ UJP PRAHA a.s., Nad Kamínkou1345, 15610 Praha-Zbraslav, Czech Republic

The objective of this work was to investigate and evaluate the effect of the composition and production on microstructure and tribological properties of cobalt alloys. The referece material was Co-28Cr-6Mo alloy, which is successfully used in the medicine for many years. The excellent corrosion resistance is the advantage, as well as better wear resistance than is offered by titanium or stainless steel implants. Standard Co-Cr-Mo alloy and also Co-Cr-Mo alloy with $\mathrm{Ti}$ in an amount $5 \mathrm{wt}$. \%, were prepared by casting and also mechanical alloying followed by "Spark Plasma Sintering" consolidation. The influence of production route as well as influence of alloying elements on the microstructure and tribological properties was observed. Based on the obtained results, the $\mathrm{Co}$ - $\mathrm{Cr}$ Mo-Ti alloy produced by casting seems to be most suitable, because the addition of titanium has greatly improved the wear resistance.

Keywords: cobalt alloy, microstructure, biomaterial, type of production

\section{Acknowledgement}

This research was financially supported by Czech Science Foundation, project No. P108/12/G043 and by specific university research (MSMT No 20-SVV/2016).

\section{References}

[1] GÜLSOY, H. Ö.; ÖZGÜN, Ö.; BILKETAY, S. (2016). Powder injection molding of Stellite 6 powder: Sintering, microstructural and mechanical properties. In: Materials Science and Engineering A, Vol. 651, pp. 914-924. Turkey.

[2] MARTI, A. (2000). Cobalt-base alloys used in bone surgery. In: Injury, Vol. 31, No.4, pp. D18-D21. Elsevier.

[3] CAWLEY, J., et al. (2003). A tribological study of cobalt chromium molybdenum alloys used in metal-on-metal resurfacing hip arthroplasty. In: Wear, Vol. 255, No. 7-12, pp. 999-1006. UK.

[4] SAWANGRAT, C., et al. (2014). Application of harmonic struture design to biomedical Co-Cr-Mo alloy for improved mechanical properties. In: Materials Transactions, Vol. 55, No. 1, pp. 99-105.

[5] SHIN, J.C., et al. (2003). Effect of molybdenum on the microstructure and wear resistance of cobalt-base Stellite hard facting alloys. In: Surface and Coatings Technology, Vol. 166, No. 2-3, pp. 117-126.

[6] BELLEFONTAINE, G. (2010). The corrosion of CoCrMo alloys for biomedical applications. In: Doctoral dissertation. University of Birmingham. UK.

[7] MATKOVIĆ, T., MATKOVIĆ, P., MALINA, J. (2004). Effects of Ni and Mo on the microstructure and some other properties of Co-Cr dental alloys. In: Journal of alloys and compounds, Vol. 366, No. 1-2, pp. 293-297. University of Zagreb. Croatia.

[8] GHIBAN, A., et al. (2014). Structural investigations in CoCrMo(Ti) welded dental alloy. In: Rev. Chim.(Bucharest), Vol. 65, No. 11, pp. 1314-1318. Romania.

[9] MONROY, K., DELGADO, J., CIURANA, J. (2013). Study of the pore formation on CoCrMo alloy by selective laser melting manufacturing process. In: Procedia engineering, Vol. 63, pp. 361-369. Universitat de Girona. Spain.

[10] ČAPEK, J., VOJTĚCH, D. (2015). Powder metallurgical techniques for fabrication of biomaterials. In: Manufacturing Technology, Vol. 15, No. 6, pp. 964-969, UCT Prague, Czech Republic.

[11] NOVÁK, P., et al. (2014). Application of microscopy and X-ray diffraction in optimization of the production of NiTi alloy by powder metallurgy. In: Manufacturing Technology, Vol. 14, No. 3, pp. 387 - 392. Czech Republic.

[12] NOVÁK, P. (2014). CZ Patent 305703.

[13] VALALIK, M., et al. (2015). Unconventional method of preparation intermetallic phases Fe-Al by mechanical alloying in comparison to reactive sintering. In: Manufacturing Technology, Vol. 15, No. 1, pp. 105 - 109. UJEP. Czech Republic.

[14] CAWLEY, J., et al. (2003). A tribological study of kobalt chromium molybdenum alloys used in metal-on-metal resurfacing hip arthroplasty. In: Wear, Vol. 255, No. 7-12, pp. 999-1006. UK. 